\title{
Mendekatkan Pelayanan Kesehatan yang Berkualitas pada Masyarakat $^{1}$
}

\author{
Agung Dwi Laksono²
}

Aksesibilitas masyarakat ke fasilitas pelayanan kesehatan adalah hak setiap orang untuk mendapatkan akses terhadap sumber daya kesehatan, termasuk di dalamnya hal untuk mendapatkan akses ke fasilitas pelayanan kesehatan. Aksesibilitas masyarakat pada fasilitas pelayanan kesehatan menjadi jauh lebih penting lagi ketika kita dihadapkan pada kondisi di Indonesia yang sangat penuh variabilitas.

Kondisi-kondisi tersebut cukup merepotkan pemerintah dalam upaya menghadirkan akses pelayanan

1 Versi ringkas dalam bentuk poster bisa dilihat di https:// www.researchgate.net/publication/315893595 M endekatkan Pe layanan Kesehatan yang Berkualitas pada Masyarakat.

DOI 10.13140/RG.2.2.21194.16327

2 Peneliti pada Pusat Penelitian dan Pengembangan Humaniora dan M anajemen Kesehatan, Kementerian Kesehatan RI. 


\section{Gugus Opini Pengarusutamaan Pencegahan Penyakit dan Promosi Kesehatan}

yang sama dan berkualitas di setiap jengkal wilayah republik ini. Tidak bisa dipungkiri kesenjangan aksesibilitas pelayanan kesehatan dengan dikotomi desa-kota, Jawa/Bali-luar Jawa/Bali, wilayah Barat-Timur, dan juga dikotomi kabupaten-kota, masih dipandang eksis hingga saat ini.

Cukup banyak upaya-upaya pemerintah yang dikeluarkan dengan kebijakan perbaikan input pelayanan kesehatan dan juga upaya mengurangi barrier. Salah satu contoh populer adalah kebijakan Nusantara Sehat yang merupakan kontrak tenaga kesehatan sebagai tim yang ditempatkan di wilayah terpencil dan sangat terpencil. Sedang JKN merupakan salah satu kebijakan untuk memperbaiki akses masyarakat ke fasilitas pelayanan kesehatan. Upaya ini merupakan salah satu cara untuk mengurangi barrier dalam hal pembiayaan.

Hasil kajian Laksono $(2016)^{3}$ yang dilakukan dengan menggunakan data tahun 2013 masih menunjukkan adanya kesenjangan dari sisi supply pada pelayanan kesehatan di Indonesia. Hal ini ditunjukkan baik dari sisi tenaga maupun fasilitas pelayanan kesehatan di Indonesia, antara wilayah kabupaten dan kota. Persebaran tenaga dokter baik dari segi jumlah maupun rasio masih lebih banyak di kota, namun demikian distribusi jumlah dan rasio bidan lebih banyak di kabupaten daripada di kota. Ketersediaan fasilitas kesehatan di Kota jauh lebih bagus dari pada di Kabupaten pada

3 Lihat Laksono, A.D., Dwi Rofingatul Mubasyiroh, Turniani Laksmiarti, Suharmiati, 2016. Aksesibilitas Pelayanan Kesehatan di Indonesia. Yogyakarta; Penerbit Kanisius. Bias diunduh di https://www.researchgate.net/publication/315892278 Aksesibilitas Pela yanan Kesehatan di Indonesia 
indikator jumlah rumah sakit (pemerintah dan swasta), total tempat tidur tersedia, maupun rasio tempat tidur dibanding dengan jumlah penduduk. Rerata jumlah Puskesmas Perawatan di Kabupaten memiliki jumlah lebih tinggi dibanding dengan Kota, namun demikian, kesenjangan supply tidak terjadi antara daerah miskin dan non miskin.

Dikotomi Jawa-Bali dengan Non Jawa-Bali, atau Kawasan Barat Indonesia dibanding Kawasan Timur Indonesia masih dirasakan cukup menjadi representasi kesenjangan aksesibilitas pelayanan kesehatan. Ketimpangan tidak hanya terjadi pada sisi supply ketersediaan fasilitas pelayanan kesehatan, tetapi juga pada supply tenaga kesehatan pada masing-masing wilayah. Keberadaan fasilitas kesehatan menurut hasil survei Riset Kesehatan Dasar (Riskesdas) tahun 2013 menunjukkan bahwa Rumah Tangga yang mengetahui keberadaan Rumah Sakit Pemerintah tertinggi di Provinsi Bali sebesar 88,6\%, sedangkan terrendah di Provinsi Nusa Tenggara Timur sebesar 39,6\%. Sedang untuk keberadaan Rumah Sakit Swasta Rumah Tangga yang mengaku ada keberadaan RS swasta di sekitar rumahnya tertinggi berada di Propinsi Daerah Istimewa Yogyakarta yang mencapai 82,4\%, dan terendah ada di Propinsi Sulawesi Barat sebesar $15,1 \%{ }^{4}$.

Tidak berbeda dengan ketersediaan fasilitas pelayanan kesehatan, ketersediaan tenaga kesehatan juga menunjukkan disparitas yang sama. Tercatat bahwa Rumah Tangga di Propinsi Bali yang mengaku mengetahui

${ }^{4}$ Lihat Badan Penelitian dan Pengembangan Kementerian Kesehatan RI., 2013. Laporan Nasional Riset Kesehatan Dasar Tahun 2013. Jakarta; Balitbangkes. 


\section{Gugus Opini Pengarusutamaan Pencegahan Penyakit dan Promosi Kesehatan}

keberadaan dokter praktek atau klinik di sekitar rumahnya mencapai 82,7\%, sedang untuk kriteria yang sama di Propinsi Nusa Tenggara Timur hanya mencapai kisaran 19,3\% saja. Pengetahuan yang sama tentang keberadaan bidan praktek dirasakan lebih jauh lagi. Tercatat bahwa Rumah Tangga di Provinsi Bali yang mengaku mengetahui keberadaan bidan praktek di sekitar rumahnya mencapai $85,2 \%$, sedang Rumah Tangga di Papua mencatat nilai terendah pada kisaran 9,9\%5.

Hasil studi yang dilakukan oleh Pusat Kebijakan dan Manajemen Kesehatan UGM Mada dengan jejaring perguruan tinggi lain (2013) dalam rangka monitoring JKN menunjukkan hasil yang senada dengan hasil Riskesdas 2013, tercatat bahwa jumlah tenaga dokter spesialis di Provinsi NTT hanya pada kisaran 65 spesialis untuk sekitar 4,6 juta penduduk, sedang di Provinsi DI. Jogjakarta tenaga dokter spesialis jauh lebih tinggi ketersediannya, mencapai sekitar 1.300 spesialis untuk sekitar 3,5 juta penduduk ${ }^{6}$.

Berbicara tentang aksesibilitas pelayanan kesehatan di Indonesia tidak bisa dilepaskan begitu saja dengan konteks yang melingkupinya. Kondisi kesenjangan sosial-ekonomi yang demikian dalam dan kondisi geografis yang cenderung ekstrem turut mempengaruhi aksesibilitas masyarakat terhadap fasilitas pelayanan kesehatan.Sedang upaya-upaya yang akan dilakukan untuk meningkatkan aksesibilitas

5 Lihat Badan Penelitian dan Pengembangan Kementerian Kesehatan RI., 2013. Laporan Nasional Riset Kesehatan Dasar Tahun 2013. Jakarta; Balitbangkes.

${ }^{6}$ Lihat Pusat Kebijakan dan Manajemen Kesehatan Universitas Gadjah M ada dan Jejaring Perguruan Tinggi, 2013. Laporan M onitoring Jaminan Kesehatan Nasional. Yogyakarta; Universitas Gadjah Mada. 
terhadap pelayanan kesehatan tersebut, mau tidak mau harus memperhatikan konteks kebijakan yang sedang berlaku positif pada saat ini. Beberapa kebijakan yang dinilai harus menjadi perhatian dalam upaya-upaya tersebut adalah Undang-Undang tentang Pemerintah Daerah, UndangUndang tentang Kesehatan, Undang-Undang tentang Tenaga Kesehatan, dan Standar Pelayanan Minimal Bidang Kesehatan.

\section{Rekomendasi Kebijakan}

Setidaknya ada enam strategi yang bisa diterapkan oleh pemerintah daerah kabupaten/kota dalam kategori perbaikan input ini. Strategi ini bisa dilaksanakan sendiri, maupun dengan memohon bantuan atau bekerjasama dengan pemerintah provinsi ataupun pemerintah pusat.

\begin{tabular}{c|l|l}
\hline No & \multicolumn{1}{|c|}{ STRATEGI } & \multicolumn{1}{c}{ PENGERTIAN } \\
\hline $\mathbf{1}$ & $\begin{array}{l}\text { Penambahan } \\
\text { jumlah tenaga/ } \\
\text { fasyankes }\end{array}$ & $\begin{array}{l}\text { M elakukan penambahan tenaga } \\
\text { kesehatan atau fasilitas kesehatan } \\
\text { sesuai kebutuhan. }\end{array}$ \\
\hline $\mathbf{2}$ & Contracting out & $\begin{array}{l}\text { M elakukan penambahan tenaga } \\
\text { kesehatan sesuai kebutuhan melalui } \\
\text { mekanisme kontrak, baik tenaga } \\
\text { kesehatan perseorangan maupun } \\
\end{array}$ \\
\hline $\mathbf{3}$ & Redistribution & $\begin{array}{l}\text { Mebagai sebuah tim kesehatan. } \\
\text { Mendistribusikan ulang tenaga }\end{array}$ \\
\hline & & $\begin{array}{l}\text { kesehatan dengan } \\
\text { mempertimbangkan beban dan }\end{array}$ \\
\hline
\end{tabular}


kebutuhan antar wilayah.

\begin{tabular}{c|c|c}
\hline 4 & Reconfiguration & $\begin{array}{l}\text { Penambahan fungsi atau kewenangan } \\
\text { terbatas tenaga kesehatan pada } \\
\text { daerah-daerah khusus untuk } \\
\text { mengatasi kekurangan jenis tenaga } \\
\text { tertentu. }\end{array}$ \\
\hline $\mathbf{5}$ & Rescheduling & $\begin{array}{l}\text { Penjadwalan ulang untuk memastikan } \\
\text { pemerataan pada suatu wilayah untuk } \\
\text { pelayanan jenis tenaga kesehatan } \\
\text { tertentu }\end{array}$ \\
\hline M obile unit & $\begin{array}{l}\text { Membentuk satu unit tim kesehatan } \\
\text { yang mampu bergerak menjangkau } \\
\text { setiap sudut wilayah yang menjadi } \\
\text { tanggung jawabnya. }\end{array}$ \\
\hline
\end{tabular}

Kabupaten/kota yang kaya bisa langsung menyelenggarakan strategi yang pertama. Pemerintah daerah dapat menambah jumlah tenaga atau fasilitas pelayanan yang dibutuhkan langsung secara mandiri.

Strategi ke-dua tidak berbeda jauh dengan strategi pertama, hanya saja tenaga kesehatan yang akan direkrut dikontrak untuk jangka waktu tertentu. Langkah perekrutan ini juga bisa dilakukan dengan mengontrak kumpulan tenaga kesehatan sebagai sebuah tim.

Langkah strategi ke-tiga sampai dengan ke-empat lebih merupakan strategi manajerial. Hal ini bisa dilakukan dengan tanpa menambahkan jumlah tenaga atau fasilitas pelayanan kesehatan. 


\section{Mendekatkan Pelayanan Kesehatan yang Berkualitas pada Masyarakat}

Strategi ke-empat, reconfiguration, adalah penambahan fungsi atau kewenangan terbatas tenaga kesehatan pada daerah-daerah khusus untuk mengatasi kekurangan jenis tenaga tertentu. $\mathrm{M}$ isalnya perawat dilatih untuk dapat melakukan APN, sementara dokter umum ditambahi dengan ketrampilan melakukan operasi caesaria, meski dalam beberapa kesempatan hal ini masih menimbulkan pro dan kontra dengan organisasi profesi.

Strategi terakhir yang bisa dilakukan untuk beberapa wilayah dengan jangkauan yang luas dan dengan jumlah tenaga dan fasilitas yang terbatas adalah dengan strategi mobile unit. Strategi ini dilakukan dengan membentuk unit khusus yang bisa bergerak secara mobile untuk menjangkau wilayah-wilayah yang tidak tersedia pelayanan, baik karena tenaga yang tidak ada maupun karena memang fasilitas pelayanan yang tidak tersedia. 
Gugus Opini Pengarusutamaan

Pencegahan Penyakit dan Promosi Kesehatan 